\title{
Application of Cow Rumen Liquid in Palm Sugar Waste Compost for Cultivating Sweet Corn in Coastal Sandy Soil of Samas Beach Bantul
}

DOI: 10.18196/pt.2017.069.96-105

\author{
Nadia Dwi Larasati*, Gunawan Budiyanto, Titiek Widyastuti \\ Department of Agrotechnology, Faculty of Agriculture, Universitas Muhammadiyah Yogyakarta, \\ Jl. Lingkar Selatan, Kasihan, Bantul, Yogyakarta 55183, Indonesia Telp. 0274387656 , \\ *Corresponding author, email: nadya.larasati77@gmail.com
}

\begin{abstract}
The research was conducted to study the effect of palm sugar waste compost using cow rumen activator on sweet corn cultivation and to determine the effective concentration of cow rumen activator and dose of sugar palm waste compost for sweet corn cultivation in coastal sandy soil of Samas Beach, Bantul. The research was arranged in Completely Randomized Design (CRD). A total of 11 treatments consisting of combination between the dose of sugar palm waste compost (tonnes/hectare) and various concentrations of cow rumen activators (\%), with detail as follows: (1) 20 tonnes/hectare and 60\%, (2) 20 tonnes/hectare and 70\%, (3) 20 tonnes /hectare and 80\%, (4) 20 tonnes/hectare and 90\%, (5) 20 tonnes /hectare and 100\%, (6) 25 tonnes/hectare and 60\%, (7) 25 tonnes/hectare and 70\%, (8) 25 tonnes/hectare and 80\%, (9) 25 tonnes/hectare and 90\%, (10) 25 tonnes/hectare and 100\%, and (1 1) 20 tonnes/hectare of inorganic fertilizer. Each treatment was replicated four times. The results showed that the treatments of sugar palm waste compost with various concentrations of cow rumen activator and commercial compost had no significant effect on almost all plant parameters, except the root fresh weight. In addition, sugar palm waste compost with various concentration of cow rumen activator produced higher fresh weight of ear with husk compared to the potential yield of Sweet Boy variety. Dose of 20 tonnes/hectare of sugar palm waste compost with cow rumen activator at a concentration of $60 \%$ is the most effective treatment for sweet corn cultivation in coastal sandy soil of Samas Beach, Bantul.

Keywords: Rumen, Sandy soil, Palm sugar waste, Compost, Sweet corn
\end{abstract}

\begin{abstract}
ABSTRAK
Penelitian bertujuan untuk mengkaji pengaruh kompos ampas aren dengan menggunakan aktivator rumen sapi pada budidaya tanaman jagung manis dan untuk mendapatkan konsentrasi aktivator rumen sapi serta dosis pemupukan ampas aren yang efektif untuk budidaya tanaman jagung manis di pasir Pantai Samas Bantul. Penelitian dirancang menggunakan Rancangan Acak Lengkap dengan faktor tunggal. Perlakuan terdiri dari 11 perlakuan kombinasi dosis kompos ampas aren dan konsentrasi aktivator rumen sapi yaitu: 20 ton/hektar dan 60\%, 20 ton/hektar dan 70\%, 20 ton/hektar dan $80 \%, 20$ ton/ hektar dan 90\%, 20 ton/hektar dan 100\%, 25 ton/hektar dan 60\%, 25 ton/hektar dan 70\%, 25 ton/hektar dan 80\%, 25 ton/hektar dan 90\%, 25 ton/ hektar dan 100\%, dan 20 ton/hektar pupuk anorganik. Setiap perlakuan diulang sebanyak empat kali. Hasil penelitian menunjukkan bahwa perlakuan dosis kompos ampas aren dengan menggunakan berbagai konsentrasi aktivator rumen sapi memberikan pengaruh yang tidak berbeda nyata pada hampir semua parameter tanaman kecuali pada parameter bobot segar akar. Bobot tongkol berkelobot dan potensi lebih tinggi pada jagung yang dipupuk dengan kompos ampas aren dengan aktivator rumen sapi dibandingkan dengan pupuk anorganik. Dosis 20 ton/hektar kompos ampas aren dengan konsentrasi aktivator rumen sapi 60\% paling efektif pada budidaya tanaman jagung manis di tanah pasir Pantai Samas Bantul.
\end{abstract}

Kata kunci: Rumen, Pasir pantai, Ampas aren, Kompos, Jagung manis

\section{INTRODUCTION}

Activator is a material that can be used to accelerate and streamline the process of composting. Cow rumen is one of potential activator sources that can be used as compost activator by breeding its microorganisms (Isnaini, 2006). Cow rumen as compost activator could produce proper compost from Lamtoro (Leucaena leucocephala) leaves based on compost standard quality (Heppy, 2011). Many organic materials can be used as compost materials. One of them is sugar palm waste. Sugar palm waste is an industrial waste that need an activator like cow rumen to cut composting time. Sugar palm waste still contains a lot of organic materials, such as $\mathrm{P}$ (Phosphor) elements as much as $487.67 \mathrm{mg} / \mathrm{kg}$ and $\mathrm{K}$ (Potassium) elements as much as 2,206.96 mg/ $\mathrm{kg}$ (Mayrina and Marisa, 2005). In sugar palm flour industrial, it just uses 10\% of C-organic to 
produce sugar palm flour based on analysis of sugar palm waste. Sugar palm waste still has high content of P (Phospor) and K (Potassium) element that can be utilized as additional organic material in the form of compost for cultivation (Parjito, 2009).

Sweet corn (Zea mays saccharata L.) is an alternative food that is widely consumed by Indonesian people. But, corn production from year to year is still not stable to fullfill the demand. Data from the Indonesian Bureau of Statistics (BPS) (2015), the corn production in 2012 was orginally 19,387,022 tonnes which decreased to $18,511,853$ tonnes in 2013 and increased to $19,032,677$ tonnes in 2014. The unstable corn production was due to the conversion of cultivation land into housing and industrial areas. Around 2000 - 2010 was 65,961 hectares paddy fields in Java and 64,300 hectares paddy fields outside Java had become non-paddy fields areas (Pusdatin, 2013).

There are increasing needs of housing and food which leads to of agricultural land conversion to fullfill it. One of solutions that can be used is the utilization of marginal land such as coastal sandy soil to produce food crops. Coastal sandy soil is a type of soil dominated by $99 \%$ sand fraction, $1 \%$ dust content and no clay content. Coastal sandy soil has no micro pore, low moisture content in root and low water storage ability (Budiyanto, 2016). It needs additional organic matter to increase physical and chemical properties (Gunawan, 2014; Hasibuan, 2015).

The research was conducted to determine the effect of sugar palm waste compost with cow rumen activator on sweet corn cultivation and to determine the effective concentration of cow rumen activator and dose of sugar palm waste compost for sweet corn cultivation in coastal sandy soil of Samas Beach, Bantul.

\section{MATERIALS AND METHODS}

The research was conducted in the Greenhouse and Field Experiment of Faculty of Agriculture, Universitas Muhammadiyah Yogyakarta from November 2015 to September 2016. The research was arranged in Completely Randomized Design (CRD). A total of 11 treatments of (a) the dose of sugar palm waste compost, and (b) various concentrations of cow rumen activators, were applied, i.e : (K1) 20 tonnes / hectare of sugar palm waste compost with cow rumen activator at a concentration of $60 \%$, (K2) 20 tonnes /hectare of sugar palm waste compost with cow rumen activator at a concentration of $70 \%$, (K3) 20 tonnes / hectare of sugar palm waste compost with cow rumen activator at a concentration of $80 \%$, (K4) 20 tonnes /hectare of sugar palm waste compost with cow rumen activator at a concentration of $90 \%$, (K5) 20 tonnes / hectare of sugar palm waste compost with cow rumen activator at a concentration of $100 \%$, (K6) 25 tonnes /hectare of sugar palm waste compost with cow rumen activator at a concentration of $60 \%$, (K7) 25 tonnes /hectare of sugar palm waste compost with cow rumen activator at a concentration of $70 \%$, (K8) 25 tonnes / hectare of sugar palm waste compost with cow rumen activator at a concentration of $80 \%$, (K9) 25 tonnes / hectare of sugar palm waste compost with cow rumen activator at a concentration of $90 \%$, (K10) 25 tonnes / hectare of sugar palm waste compost with cow rumen activator at a concentration of $100 \%$, and (K11) 20 tonnes / hectare of commercial compost. Each treatment was replicated four times.

The steps of making cow rumen activator were: 1) $2.03 \mathrm{~kg}$ of brown sugar was boiled in water until the sugar melted. 2) $6.09 \mathrm{~kg}$ of rice sifting and 609.23 grams of terasi (fermented condiment made from finely crushed shrimp or 
krill mixed with salt) were added into the sugar liquid and then were cooled in bucket. 3) 2.03 liters of cow rumen liquid was added into mixture of sugar, rice sifting and terasi after the mixture were cooled. 4) The mixture was stirred well and the mixture was stored in bucket and covered until two days. 5) On the third day, the mixture was stirred for about 10 minutes and repeated every 24 hours. 6) Activator was ready to use after 5 days fermentation (Isnaini, 2006). The results of cow rumen activator at a concentration of $100 \%$ and other concentration $(60 \%, 70 \%, 80 \%$ and $90 \%)$ should be diluted from cow rumen activator concentration of $100 \%$.

Sugar palm waste compost with various concentration of cow rumen activator was made by preparing sugar palm waste and cow rumen activator according to the concentration treatment. According to Heppy (2011), 500 grams of lamtoro (Leucaena leucocephala) leaves composting required $550 \mathrm{ml}$ of cow rumen activator. Composting was done for 2 months by doing a reversal every single week. Parameters observed were $\mathrm{pH}$ value, compost temperature, $\mathrm{C}$-organic content and N-total content.

Each polybag has 600 grams (for 20 tonnes/ hectare dose) and 750 grams (for 25 tonnes/ hectare) of sugar palm waste compost. The filtered coastal sandy soil was mixed with sugar palm waste compost then put into a polybag with size of $35 \mathrm{~cm}$ x $35 \mathrm{~cm}$. Six grams Urea, 9 grams SP-36 and 7.5 grams $\mathrm{KCl}$ were also added into the mixed coastal sandy soil and sugar palm waste compost. After that, the planting media was incubated for one week before the seeding. Planting step was done by immersing two sweet corn seed in each polybag treatment at $\pm 4 \mathrm{~cm}$ from soil surface. Maintenance for sweet corn cultivation included watering, replanting, fertilizing, pest control and harvesting. Sweet corn growth analysis included plant height, number of leaves, stem diameter, plant fresh weight, plant dry weight, root fresh weight, root dry weight, fresh weight of ear with husk and diameter of ear with husk.

The data obtained were analysed using Analysis of Variance (ANOVA) with $\alpha=5 \%$. Data showing significant effect among treatments were tested using Duncan's Multiple Range Test (DMRT) with $\alpha=5 \%$.

\section{RESULTS AND DISCUSSIONS}

Sugar Palm Waste Compost Observation

Compost observation was carried out to know the appropriateness of sugar palm waste compost before it was applied to sweet corn cultivation. The results of compost observation were shown in Table 1.

Table 1. Composition of Sugar Palm Waste Compost

\begin{tabular}{|c|c|c|c|c|c|c|}
\hline Treatments & $\mathrm{pH}$ & Temperature $\left({ }^{\circ} \mathrm{C}\right)$ & Organic matter content (\%) & C-organic content (\%) & $\mathrm{N}$ total content $(\%)$ & C/N Ratio \\
\hline SNI of Compost & $6.80-7.49$ & Groundwater temperature & $27-58$ & $9.80-32$ & $>0.40$ & $10-20$ \\
\hline Sugar palm waste & 5.99 & - & 26.54 & 15.34 & 1.14 & 13.46 \\
\hline KA 1 & 7.35 & 26.00 & 36.66 & 21.26 & 2.04 & 10.42 \\
\hline KA 2 & 7.30 & 26.70 & 32.98 & 19.13 & 2.15 & 8.89 \\
\hline KA 3 & 7.50 & 27.30 & 35.80 & 20.76 & 2.16 & 9.61 \\
\hline KA 4 & 7.46 & 26.00 & 33.03 & 19.16 & 2.27 & 8.44 \\
\hline KA 5 & 7.19 & 28.00 & 46.53 & 26.98 & 2.12 & 12.72 \\
\hline
\end{tabular}

Note: 


\section{pH Level of Compost}

The $\mathrm{pH}$ level of compost is one of the components that needs to be considered in composting because it is an indicator of living microorganisms during the composting process (Happy, 2014). The $\mathrm{pH}$ level of sugar palm waste compost using various concentrations of cow rumen activator was in accordance with the Indonesian National Standard (SNI: 19-7030-2004) (Table 1). The standard $\mathrm{pH}$ level of compost that was between 6.80 and 7.49 (Eviati and Sulaeman, 2009). Figure 1 showed that most of the treatments increased $\mathrm{pH}$ level from the initial composting process up to the end of composting process (mature compost) from the acid $\mathrm{pH}$ level to neutral. The decrease in $\mathrm{pH}$ was caused by the decomposition of organic matter into organic acids. The organic acids would be converted in methane and $\mathrm{CO}_{2}$. After that, $\mathrm{pH}$ would increase as a result of protein degradation and eventually have a neutral pH (Firda, 2013; Joko, et. al., 2010).

\section{Temperatures}

Compost temperature indicates that decomposed microorganisms from sugar palm waste and cow rumen activator undertake decomposition process according to the condition of the composting process. Compost temperature obser- vations were conducted to determine the stage of composting and compost maturity based on the microorganisms activity (Tchobanglous et. al., 2002 cit. Kusuma, 2012)

Based on Figure 1(b), the temperature fluctuations during composting period indicated that each treatment was only capable of reaching a peak temperature between $36^{\circ} \mathrm{C}-38.7^{\circ} \mathrm{C}$. Treatment that had reached the highest temperature was sugar palm waste composting using cow rumen activator at a concentration of $70 \%$ (KA 2) (Table 1).

Composting process didn't reach the thermophilic phase because it was affected by the type and particle size of the materials. Sugar palm waste was included in lignocelluloses biomass that had lignin content between 46-52\% (Fadilah and Sperisa, 2009). High content of lignin caused the sugar palm waste difficult to decompose. It was because the type of materials affected the smooth $\mathrm{O}_{2}$ diffusion required as well as the resulting $\mathrm{CO}_{2}$ expenditure. The particle size of materials served in $\mathrm{O}_{2}$ movement in the compost pile (relation to porosity), microorganism access and enzymes for substrate (Nan, et. al., 2005; Happy, 2014). Sugar palm waste had small particle size that made compost piles have fewer air cavities and supply of $\mathrm{O} 2$ reduced.

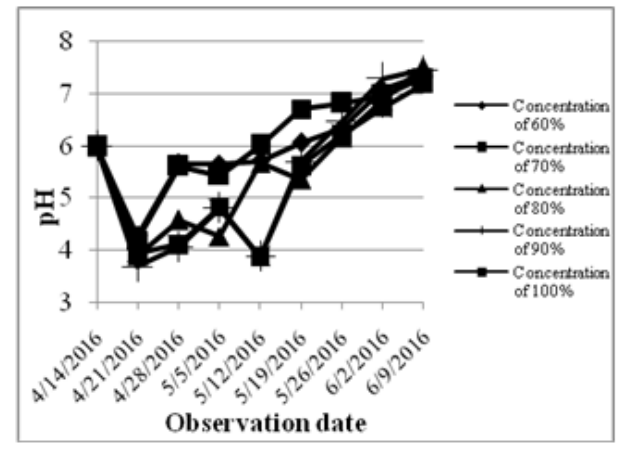

(a)

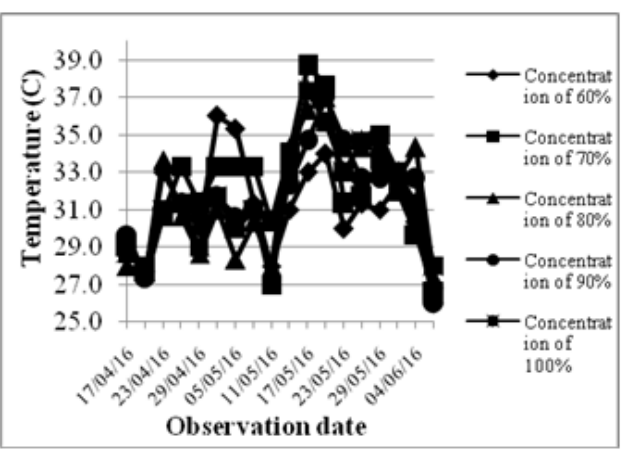

(b)

Figure 1. pH level of sugar palm waste composting (a) and Composting temperature (b) 


\section{Organic Matter Content}

Organic matter content in compost has related to the Carbon content. Organic matter is energy source, carbon and nutrients for microorganisms (Happy, 2014). Organic matter content in sugar palm waste compost using various concentration of cow rumen activator was in accordance with SNI: 19-7030-2004 for standard content of organic matter (Table 1) (Eviati and Sulaeman, 2009). Sugar palm waste compost using various concentration of cow rumen activator has organic matter content between $36-46 \%$. It could fix soil nature and soil absorption capacity of water as well as raise the living conditions in the soil and nutrients source for plants (Pinus, 2003).

\section{C-organic content}

In decomposition process, carbon is energy source for microorganisms. It is used to arrange the cells of microorganisms by releasing $\mathrm{CO}_{2}$ and other volatile materials (Mohamad, 2008). The content of C-organic generally tend to decrease after decomposition process is completed. But the result in this research showed that all treatments increased C-organic content (Table 1). Increased levels of C-organic was becaused of some microorganisms has been dead and they were not able to degrade organic substance (Laksana and Chaerul in Anand, 2014). However, sugar palm waste compost using various concentration of cow rumen activator was in accordance with SNI: 19-7030-2004 for standard content of C-organic which was between 9.8-32 \% (Table 1) (Eviati and Sulaeman, 2009).

\section{N-total content}

$\mathrm{N}$-total content affected $\mathrm{C} / \mathrm{N}$ ratio and used to know the appropriateness of compost. The result showed that in all treatments increased the levels of $\mathrm{N}$ total due to decomposition process of compost by microorganisms that produced ammonia and Nitrogen (Andhika and Dodi, 2009). The result of $\mathrm{N}$-total content from all treatments was in accordance with SNI: 19-7030-2004 (Table 1) (Eviati and Sulaeman, 2009).

\section{$\mathrm{C} / \mathrm{N}$ Ratio}

$\mathrm{C} / \mathrm{N}$ ratio is used to evaluate the appropriateness of compost before it is applied to the crop cultivation. Sugar palm waste compost using cow rumen activator at a concentration of $60 \%$ and $100 \%$ were in accordance with SNI: $19-7030$ 2004, but other treatments were not, for the standard of $\mathrm{C} / \mathrm{N}$ ratio which ranged between 10-20 (Table 1) (Eviati and Sulaeman, 2009). The sugar palm waste compost using various concentration of cow rumen activator had varied result of $\mathrm{C} / \mathrm{N}$ ratio. It was because of the various concentration of cow rumen activator applied to sugar palm waste.

Vegetative Growth Phase of Sweet Corn Cultivation

Plant height was measured from the base of the stem to the growing point of sweet corn plants. The result of analysis of variance for the plant height showed that all treatments demonstrated no significant different effect on the growth of sweet corn plants (Table 2). Sufficiency of nutrients in corn crops caused the higher compost dose not to give significant effect on the growth of sweet corn plants (Karwan, 2003).

Based on Figure 2a, all treatments demonstrated a similar pattern of plant height growth. Sugar palm waste compost and commercial compost demonstrated no significant different effect. It proved that sugar palm waste compost can be used as source of organic matter applied to coastal sandy soil. Compost helped reduce nutrient leaching and provided nutrients for plants. 
Table 2. Plant Height, Number of Leaves and Stem Diameter of Corn Plants

\begin{tabular}{cccc}
\hline Treatments & Plant height $(\mathrm{cm})$ & $\begin{array}{c}\text { Number of leaves } \\
\text { (sheet) }\end{array}$ & $\begin{array}{c}\text { Stem diameter } \\
\text { (cm) }\end{array}$ \\
\hline K1 & 210.00 & 11.50 & 1.790 \\
K2 & 203.25 & 12.50 & 1.865 \\
K3 & 192.50 & 12.75 & 1.773 \\
K4 & 199.00 & 11.75 & 1.911 \\
K5 & 160.75 & 11.50 & 1.747 \\
K6 & 216.00 & 12.75 & 1.945 \\
K7 & 194.25 & 12.75 & 1.867 \\
K8 & 202.75 & 11.50 & 1.712 \\
K9 & 224.50 & 12.25 & 1.824 \\
K10 & 197.00 & 11.25 & 1.923 \\
K11 & 178.00 & 11.25 & 1.789 \\
\hline
\end{tabular}

Note: Numbers in the table indicate there were no significant difference based on analysis of variance with $\alpha=5 \%$

The result of analysis of variance for the number of leaves showed that all treatments demonstrated no significant different effect on the growth of sweet corn plants (Table 2). Sugar palm waste compost helped improve the efficiency of $\mathrm{N}$ from inorganic fertilizer affecting the number of leaves. Fertilizer application on marginal land can save the water use (Sugeng,
2005). Sugar palm waste compost using various concentration of cow rumen activator applied on coastal sandy soil could increase water absorption of soil. That condition could increase the storage of $\mathrm{N}, \mathrm{P}, \mathrm{K}$ nutrients which are absorbed gradually according to the plant needs and avoid the leaching process.

Based on Figure 2b, the average number of leaves on each treatment tends to increase every week. The similar effect on number of leaves parameter had relation with plant height parameter that no significant different effect in all doses treatments (Table 2). The increasing number of leaves depends on the increasing of plant height as well as the amount segment in stem (Gardner et al., 2008).

Stem diameter was observed on the 8th week after planting in maximum vegetative phase (Figure 2c). The result analysis of variance showed that all doses treatments demonstrated no significant different effect on the stem diameter parameter (Table 2). No significant different effect

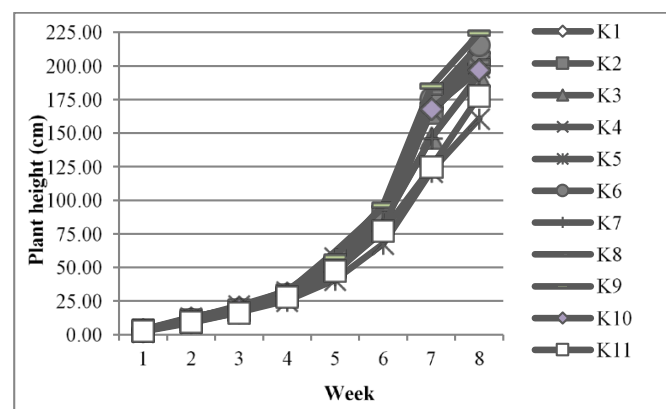

(a)

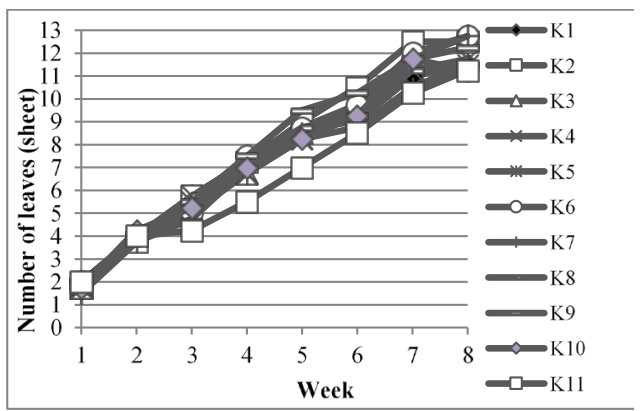

(b)

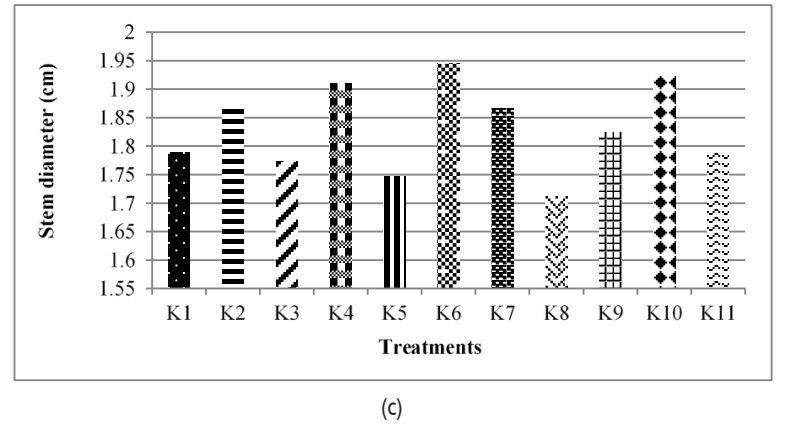

Figure 2. Plant Height (a), Number of Leaves (b), and Stem Diameter (c) 
of doses of 20 tonnes/hectare and 25 tonnes/ hectare showed that sugar palm waste compost using various concentrations of cow rumen activator could be used as organic fertilizer with recommendation dose for cultivation in conventional land that was 20 tonnes/hectare (Himmah, 2010). Meanwhile, the recommendation of giving organic matter to the coastal sandy soil was 30-40 tonnes/hectare from various sources of organic matter (Gunawan, 2014). Sugar palm waste compost using various concentration of cow rumen activator helped improve the physical and chemical properties of coastal sandy soil which could replenish the nutritional needs of the plants.

\section{Generative Growth Phase of Sweet Corn Cultivation} Fresh Weight of Ear

Fresh weight of ear is a parameter used to describe the production of sweet corn plants in a single growing season. The weight of ear observed were the weight of ear with husk and the weight of ear without husk.

Table 3. Generative Growth Variables of Sweet Corn Plants

\begin{tabular}{cccc}
\hline Treatments & $\begin{array}{c}\text { Weight of ear } \\
\text { with husk (g) }\end{array}$ & $\begin{array}{c}\text { Weight of ear } \\
\text { without husk (g) }\end{array}$ & $\begin{array}{c}\text { Diameter of ear } \\
\text { with husk (cm) }\end{array}$ \\
\hline K1 & 388.75 & 302.00 & 4.919 \\
K2 & 411.75 & 323.00 & 5.664 \\
K3 & 335.75 & 265.25 & 5.501 \\
K4 & 392.00 & 296.25 & 5.605 \\
K5 & 267.25 & 215.75 & 5.459 \\
K6 & 444.00 & 365.50 & 5.121 \\
K7 & 345.75 & 263.00 & 5.986 \\
K8 & 396.00 & 325.50 & 5.535 \\
K9 & 405.00 & 317.50 & 5.525 \\
K10 & 389.50 & 317.25 & 5.168 \\
K11 & 323.25 & 281.50 & 5.690 \\
\hline
\end{tabular}

Note: Numbers in the table indicate there were no significant difference based on analysis of variance with $\alpha=5 \%$

Both types of ear weight observed were used to determine the difference between total pro- duction of sweet corn and the net production from ear without husk in sweet corn cultivation. Based on analysis of variance, each treatment demonstrated no significant different effect on the weight of ear with husk and the weight of ear without husk (Table 3). Sugar palm waste compost and commercial compost as source of organic matter could substitute manure on the cultivation of sweet corn in coastal sandy soil. Either sugar palm waste compost or commercial compost supplied complex nutrients on sweet corn plant growth in small quantities and improved the properties of coastal sandy soil. Application of sugar palm waste compost and commercial compost to the coastal sandy soil could increase water content and availability for sweet corn cultivation.

The average difference of the weight of ear with husk and ear without husk on all treatments was \pm 75 grams. It means that weight of ear with husk would not be as heavy as the weight of ear without husk because it was influenced by the husk weight. Weight of ear especially the weight of sweet corn seeds was influenced by nutrient uptake used in the formation of proteins, carbohydrates and lipids (Soetoro et al., 1988 cit Megi, 2011).

\section{Diameter of Ear with husk}

Result of analysis of variance demonstrated no significant different effect in the dose of sugar palm waste compost or commercial compost on the diameter of ear with husk (Table 3). Each treatment of compost dose provided the same nutrient sufficiency affecting the diameter of ear with husk.

Based on Table 3, each treatment of compost dose had average diameter of ear with husk which ranged from 4.9 to $5.9 \mathrm{~cm}$. Dose of 25 tonnes/hectare of sugar palm waste compost 
using cow rumen activator at a concentration of $70 \%$ produced the largest diameter of ear with husk. The diameters of ear with husk from all treatments were bigger than that of Sweet Boy variety which was $4.8 \mathrm{~cm}$. It showed that the application of sugar palm waste compost in coastal sandy soil could fulfill nutrient needs of sweet corn plants, the diameter of ear with husk.

\section{Plant Growth Accumulation of Sweet Corn Plants}

Plant biomass is one of the most common parameter used to describe the plant growth because it is easy to measure the estimation of plant biomass and it is also an integration of all processes that occurred in plants during their life cycle (Sitompul and Bambang, 1995).

\section{Plant fresh weight}

Sweet corn plant increased the biomass weight during the vegetative growth phase, because it would increase the weight of ear with husk during the generative growth phase. Result of analysis of variance demonstrated no significant different effect among all treatments on the plant fresh weight (Table 4). Sugar palm waste compost and commecial compost affected the roots growth more than the plant fresh weight. It was because compost helped roots absorb nutrients and water from media and improved the physical and chemical properties of coastal sandy soil. Sugar palm waste compost and commercial compost also substituted manure as source of organic matter in coastal sandy soil which would increase the growth and production of plants (Rahma et. al., 2015). Plant fresh weight was affected by plant height, number of leaves and stem diameter (vegetative growth phase). Besides, plant fresh weight was also affected by root fresh weight.

\section{Roots fresh weight}

According to Weaver (1926) in Gardner, et al. (2008) roots have several major functions such as taking role in the absorption, anchorage, storage, transport and culture. The analysis of variance showed that there was significant different effect among all treatments on the roots fresh weight (Table 4). The $\mathrm{K} 7$ and $\mathrm{K} 8$ treatments were the treatments that gave the best effect compared to other treatments but. The K10 was the treatment that gave the worst effect on the roots fresh weight.

Table 4. Plant growth accumulation of sweet corn

\begin{tabular}{ccccc}
\hline Treatments & $\begin{array}{c}\text { Plant fresh } \\
\text { weight }(\mathbf{g})\end{array}$ & $\begin{array}{c}\text { Plant dry } \\
\text { weight }(\mathbf{g})\end{array}$ & $\begin{array}{c}\text { Roots fresh } \\
\left.\text { weight }(\mathbf{g})^{*}\right)\end{array}$ & $\begin{array}{c}\text { Roots dry } \\
\text { weight }(\mathbf{g}){ }^{*}\end{array}$ \\
\hline K1 & 462.73 & 83.10 & $120.15 \mathrm{ab}$ & 17.895 \\
K2 & 393.00 & 83.84 & $63.90 \mathrm{bc}$ & 14.218 \\
K3 & 358.60 & 76.93 & $64.55 \mathrm{bc}$ & 10.250 \\
K4 & 431.68 & 93.97 & $77.73 \mathrm{abc}$ & 14.405 \\
K5 & 424.25 & 71.85 & $99.38 \mathrm{abc}$ & 13.245 \\
K6 & 482.93 & 109.27 & $118.58 \mathrm{ab}$ & 24.908 \\
K7 & 516.08 & 112.58 & $138.73 \mathrm{a}$ & 26.300 \\
K8 & 459.08 & 90.61 & $158.40 \mathrm{a}$ & 21.608 \\
K9 & 510.68 & 106.09 & $126.93 \mathrm{ab}$ & 21.768 \\
K10 & 351.88 & 72.49 & $46.78 \mathrm{c}$ & 11.065 \\
K11 & 407.93 & 76.62 & $112.25 \mathrm{ab}$ & 16.258 \\
\hline
\end{tabular}

Note: Numbers followed by different letters in the same column indicate significant different effect based on Duncan's Multiple Range Test at significance level of $5 \%$. $*$ ) $=$ Result of transformation of square root
*

Significant different effect on roots fresh weight indicated that dose of 25 tonnes/hectare of sugar palm waste compost using cow rumen activator at concentration of $70 \%$ and $80 \%$ gave better effect to increase the roots fresh weight than the other treatments. Because the roots growth was not inhibited in that treatments. According to Gardner, et. al. (2008), low porosity or high density of clumps would cause limited functional and growth of roots. The $\mathrm{K} 7$ and $\mathrm{K} 8$ treatments resulted better ability of water absorption than the other treatments. The ability of water absorption would affect cell turgor pres- 
sure which is related to plant growth and development, like roots growth (Solichatun, et. al., 2005).

\section{Plant dry weight}

Plant dry weight was used to determine the plant growth accumulation which already became constant materials. Result of analysis of variance showed that all treatments gave no significant different effect on plant dry weight (Table 4). Each treatment gave no significant different effect that was affected by the absorption of nutrients and metabolic processes in sweet corn plants. Plant dry weight is the results of photosynthesis, nutrients uptake and water absorption. Plant dry weight could indicate plant productivity because $90 \%$ of photosynthesis product is in the form of dry weight form (Gardner et al., 2008).

\section{Roots dry weight}

Roots dry weight was used to know the ability of root to absorb and store water and nutrients. There was possible difference degree between root fresh weight and root dry weight that were affected by water level in root tissue and environmental factors (Sitompul and Bambang, 1995). Result of analysis of variance showed that all treatments gave no significant different effect on the roots dry weight (Table 4). The assimilates accumulation in roots was similar in all treatments. The significant different effect in roots fresh weight was also affected by water content which would not affect the roots dry weight.

The higher dose of sugar palm waste compost on sweet corn cultivation in coastal sandy soil didn't give different effect on root cell enlargement, but gave effect on root elongation. However, either sugar palm waste compost or commercial compost with the same dose gave the same effect to on the roots dry weight (Sugeng, 2005).

\section{CONCLUSIONS}

1. Sugar palm waste compost with various concentration of cow rumen activator could be used as source of organic matter for sweet corn cultivation in coastal sandy soil of Samas Beach, Bantul that gave the same effect with commercial compost, except the root fresh weight and it could produce higher weight of ear with husk compared to the potential yield of Sweet Boy variety.

2. Dose of 20 tonnes/hectare of sugar palm waste compost with cow rumen activator at a concentration of $60 \%$ was the most effective treatment for sweet corn cultivation in coastal sandy soil of Samas Beach, Bantul.

\section{ACKNOWLEDGEMENTS}

Thanks to PT. Indofood Sukses Makmur, Tbk that has provided research grants through Indofood Riset Nugraha 2015/2016 program.

\section{REFERENCES}

Anang A. 2014. Karakteristik Fisika-Kimia Pengomposan Limbah Kulit Durian (Durio zibethinus L.) Menggunakan Cairan Rumen Sapi. Jurnal Protobiont 3(3) : 75-80.

Andhika C. T. S. and Dodi A. N. 2009. Pembuatan Kompos dengan Menggunakan Limbah Padat Organik (Sampah Sayuran dan Ampas Tebu). Naskah Publikasi. Universitas Diponegoro.

BPS. 2015. Tabel Data Produksi, Produktivitas dan Luas Panen Jagung (Tabel Dinamis). http://bps.go.id/site/resultTab.

Budiyanto, G. (2016). Pengendalian Pencucian Senyawa Nitrat Guna Meningkatkan Produktivitas Lahan Marginal Pantai KuIon Progo DIY. PLANTA TROPIKA: Jurnal Agrosains (Journal Of Agro Science), 4(1), 46-57. doi:http://dx.doi.org/10.18196/ pt.2016.056.46-57.

Diah E. and Mochammad N. 2011. Pertumbuhan Tanaman Jagung (Zea mays L.) Varietas BISI-2 pada Pasir Reject dan Pasir Asli di Pantai Trisik Kulonprogo. J. Manusia dan Lingkungan 18(3) : 220-231.

Estri P., Muhammad R. A. C., Yoga P., Yulfa I. Y. and Yudia T. K. 2013. "Briquette La Bendo", Pemanfaatan Limbah Ampas Onggok menjadi Bisnis Briket Sebagai Pmberdayaan Masyarakat Dusun Bendo Desa Daleman Kecamatan Tulung Kabupaten Sleman. Makalah Publikasi. Universitas Gadjah Mada.

Eviati and Sulaeman. 2009. Analisis Kimia Tanah, Air dan Pupuk. Balai Penelitian Tanah. Bogor. 230 p. 
Fadilah and Sperisa D. 2009. Delignifikasi Ampas Batang Aren : Pembandingan Pengaruh Penambahan Glukosa dengan Penambahan Tetes. Ekuilibrium 8(2) : 19-25.

Firda H. 2013. Bioactivators Effectiveness and Utilization in Bulking Agents of Water Hyacinth as Compost. Universitas Islam Kalimantan Muhammad Arsyad Al-Banjari. 35-44p.

Gardner, F.P., R. B. Pearce and R. L. Mitchell. 2008. Fisiologi Tanaman Budidaya (translate by Herawati Susilo). UI-Press. Jakarta. 428 p.

Gunawan B. 2009. Bahan Organik dan Pengelolaan Nitrogen Lahan Pasir. UNPAD Press. Bandung. 192 p.

Gunawan B. 2014. Manajemen Sumber Daya Lahan. LP3M UMY. Yogyakarta. $67 \mathrm{p}$.

Happy M. 2014. Kajian Teori dan Aplikasi Optimasi Perancangan Model Pengomposan. Trans Info Media. Jakarta. 314 p.

Hasibuan, A. (2015). Pemanfaatan Bahan Organik dalam Perbaikan Beberapa Sifat Tanah Pasir Pantai Selatan Kulon Progo. PLANTA TROPIKA: Jurnal Agrosains (Journal Of Agro Science) 3(1): 31-40. doi:http://dx.doi.org/10.18196/pt.2015.037.3140.

Himmah A. H. 2010. Perkembangan Populasi Kutu Daun Rhopalosiphum maidis Fitch (Hemiptera : Aphididae) dan Musuh Alaminya pada Tanaman Jagung Manis (Zea mays saccharata Sturt). Skripsi S1. Institut Pertanian Bogor. 74 p.

Isnaini, M. 2006. Pertanian Organik. Kreasi Wacana. Yogyakarta. Joko N. W. K., Nur S. B. and Tri N. 2010. Pengaruh Variasi Jumlah dan Jenis Bulking Agent pada Pengomposan Limbah Organik Sayuran dengan Komposter Mini. Prosiding Seminar Nasional Perteta. Purwokerto. 606-611p.

Karwan. A. S. 2003. Sistem Pertanian Berkelanjutan. Cetakan ke-3. Kanisius. Yogyakarta. $126 \mathrm{p}$.

Kusuma, M. A. 2012. Pengaruh Variasi Kadar Air terhadap Laju Dekomposisi Kompos Sampah Organik di Kota Depok. Tesis. Sekolah Pascasarjana. Universitas Indonesia.

Mayrina F. and Marisa H. 2005. Studi Karakteristik Dasar Limbah Industri Tepung Aren. J. Infrastruktur dan Lingkungan Binaan. $1(2): 22-29$.

Megi S. 2011. Pengaruh Beberapa Dosis Kompos Jerami Padi dan Pupuk Nitrogen terhadap Pertumbuhan dan Hasil Jagung Manis (Zea mays saccharata Sturt.). J. Tanaman Pangan -: 1-7.

Mohamad M. 2008. Optimasi Pengomposan Sampah Kebun dengan Variasi Aerasi dan Penambahan Kotoran Sapi sebagai Bioaktivator. J. Ilmiah Teknik Lingkungan 4(1): 1-6.

Nan D., Kristian and Budi S. S. 2005. Cara Cepat Membuat Kompos. AgroMedia Pustaka. Jakarta. 74 p.

Parjito. 2009. Pemanfaatan Limbah Aren Desa Daleman Sebagai Bahan Baku Kompos Untuk Pembuatan Pupuk Granulat dengan Komposisi Kompos, Urea dan Zeolit. http://etd.repository. ugm.ac.id/.

Pinus L. 2003. Petunjuk Penggunaan Pupuk. Penebar Swadaya. Jakarta. $160 \mathrm{p}$.

Solichatun, Endang A. and Widya M. 2005. Pengaruh Ketersediaan Air terhadap Pertumbuhan dan Kandungan Bahan Aktif Saponin Tanaman Ginseng Jawa (Talinum paniculatum Gaertn.). J. Biofarmasi 3(2): 47-51.
Rahma Y. H., Y. B. Suwasono Heddy and Yogi S. 2015. Pengaruh Jarak Tanam dan Dosis Pupuk Kotoran Kambing terhadap Pertumbuhan dan Hasil Tanaman Buncis (Phaseolus vulgaris L.). J. Produksi Tanaman 3(49): 294-301.

Sitompul, S. M. and Bambang G. 1995. Analisis Pertumbuhan Tanaman. Gadjah Mada University Press. Yogyakarta. 409$412 \mathrm{p}$.

Sugeng W. 2005. Kesuburan Tanah Dasar Kesehatan dan Kualitas Tanah. Gava Media. Yogyakarta. 269 p. 